\title{
Geology and ore deposits of the Urals
}

\author{
Evgeny V. Pushkarev • Oskar A. R. Thalhammer • Giorgio Garuti
}

Published online: 19 January 2013

(C) Springer-Verlag Wien 2013

The Urals is a N-S trending mountain range forming the geographic boundary between Europe and Asia. It represents a $2000 \mathrm{~km}$ long Paleozoic orogen, extending from the Islands of Novaya Zemlya in the north to the Aral Sea in the south. For a long time the information about Uralian geology was very scarce in the international literature. A significant breakthrough took place at the end of 20th century when the EUROPROBE and GEODE international projects started. In the frame of these projects, several seismic cross sections trough the Urals, together with detailed geological investigations, were carried out. The main results of these studies were published in a special Issue of Tectonophysics (1997) and in the Geophysical Monograph 132 "Mountain Building in the Uralides: Pangea to the Present" published by American Geophysical Union (AGU) in 2002 and in numerous other papers. In the last decade a lot of new mineralogical, petrological and geochemical data, particularly in isotope geochemistry and geochronology, were gathered. These new data represents the base for the need for a further look onto Uralian geology. This special issue of Mineralogy \& Petrology contains a profound collections of new data, interpretations and discussional aspects on Uralian geology since 2002 .

The Urals belongs to the western flank of the huge transcontinental Uralo-Mongolian fold belt and comprises at least three billion years of geological history. Today we can distinguish between five major structural levels and

E. V. Pushkarev $(\bowtie)$

Institute of Geology and Geochemistry, Ural Division,

Russian Academy of Sciences, Pochtovy, 7,

Yekaterinburg 620075, Russia

e-mail: Pushkarev@igg.uran.ru

O. A. R. Thalhammer $\cdot$ G. Garuti

Department of Applied Geosciences and Geophysics,

Montanuniversitaet Leoben, Peter-Tunner Straße 5,

8700, Leoben, Austria epochs of the Urals development (see Puchkov 2013). The earliest Archean and later Meso-Neoproterozoic complexes, although related to the development of the Baltic craton and its eastern periphery, far before the Uralides existed, are incorporated in the Uralian orogen structure and sometimes they display traces of young Paleozoic events of the fold belt. The Archean rocks are represented by granulites of the Taratash complex, showing similarities to the granulites in the basement of the East-European platform. The MesoNeoproterozoic sedimentary and magmatic complexes witness the geotectonic development along the eastern margin of the Baltic Shield. This time was very productive regarding the formation of some important mineral deposits, such as siderite and magnesite within metasedimentary sequences (Prochaska and Krupenin 2012) and titano-magnetite ore associated with rift-related layered gabbro intrusions and others.

The Paleozoic-Lower Jurassic period of time may be considered as the main stage of the development of the Uralides, covering a complete Wilson cycle: starting from the rifting of the Baltic continent after the Timanian orogeny, through formation of an oceanic basin, a passive continental margin and microcontinental blocks, to subduction, accompanied by a significant amount of volcanic eruptions, then arc-continent collision, continent-continent collision with granite magmatism, formation of a long chain of batholiths, and finally post-collisional extension with floodbasalt magmatism. The most important and famous volcanic, intrusive, metamorphic and sedimentary complexes and related deposits in the Urals were formed during this period of time. The world-class podiform chromite deposits related to the Kempirsay ophiolite complex in the Southern Urals were formed during oceanic-island arc development. The giant Gay, Sibay and Uchaly volcanic massive sulfide deposits and many numerous small ones are located within the Devonian island-arc volcanics of the Magnitogorsk zone 
in the Southern Urals. Platinum ore and the unique platinum placer deposits belong to the Ural Platinum Belt consisting of 14 large dunite-clinopyroxenite-gabbro massifs of the Uralian-Alaskan-type, and are of Low-Middle Paleozoic age. Famous magnetite skarn and gold deposits related to the Upper Paleozoic granite and syenite massifs, are widespread all over the Urals. Thus, the Urals can be considered as the key location for investigation of relationships between different igneous rocks and various ore deposits. Fershtater (2012) wrote a comprehensive overview on the Paleozoic magmatism of the Urals. He suggested that the Urals belong to the so-called "cold orogen", according to the model by Maruyama, Santosh and Zhoo (2007), where the giant subduction in the Paleozoic created a fluid enriched mantle. Fershtater (2012) further concluded that the most of the petrological and geochemical features of the igneous rocks and associated ore deposits show a clear link to a fluid enriched mantle.

During the Silurian and Devonian subductions an enormous amount of island arc volcanic rocks all over the Urals were formed. This stage was highly productive regarding VMS deposits. It is only recently, that new evidences showed the formation of some Uralian VMS deposits through black smoker chimneys. Thus, the Urals became one of the first places in the world, where paleo-chimneys of Devonian age were described (see Maslennikov et al. 2012).

The development of the continental margin and related island arcs in the Upper Paleozoic produced very unusual sub-volcanic acid rocks containing exotic assemblages of phenocrysts, such as: epidote, titanite, garnet, apatite, muscovite, biotite and amphibole. The formation and coexistence of these primary magmatic mineral phases is the result of high fluid enrichment of acid melts under high pressure (see Pribavkin et al. 2012).

Ultramafic and mafic rock sequences of oceanic and island-arc origin dominate in the Uralian fold belt. Granitic rocks mostly appear at the collisional stage close to the final episode of the development of the Urals. The marginal oceanic setting of the Uralides explains why typical platform magmatic complexes, such as kimberlite and alkalineultramafic complexes with carbonatites, are lacking during the Paleozoic history of the Urals. However, there are several microcontinental blocks incorporated in the Uralian fold belt. The most famous microcontinental block, the Ilmeny-Vishnevogorsk, is situated in the central part of the belt and is characterized by a very complicated nepheline syenite magmatism accompanied by carbonatite intrusions. They are marked by fenite aureoles and host significant rareearth element deposits. Contrary to typical intracontinental carbonatites, these Uralian carbonatite complexes were described not so long ago, represent a very interesting petrological target and were termed "linear carbonatites" (see the paper on linear-type Uralian carbonatite related with nepheline syenite of the Ilmeny-Vishnevogorsk alkaline complex by Nedosekova et al. 2012).

It is the intention that this special issue of Mineralogy and Petrology offers an actual overview on Uralian geology, new data on magmatic rock sequences and ore deposits since 2002. This issue is determined to attract the interest of geoscientists, researchers and students and everybody interested in orogenic belts of the Uralian type.

\section{References}

Fershtater GB (2012) The main features of the Uralian Paleozoic magmatism and the epioceanic nature of the orogen. Miner Petrol. doi:10.1007/s00710-012-0218-6

Maslennikov VV, Maslennikova SP, Large RR, Danyushevsky LV, Herrington RJ, Stanley CJ (2012) Tellurium-bearing minerals in zoned sulfide chimneys from $\mathrm{Cu}-\mathrm{Zn}$ massive sulfide deposits of the Urals, Russia. Miner Petrol. doi:10.1007/s00710-012-0230-x

Nedosekova IL, Belousova EA, Sharygin VV, Belyatsky BV, Bayanova TB (2012) Origin and evolution of the Ilmeny-Vishnevogorsky carbonatites (Urals, Russia): insights from trace-element compositions, and $\mathrm{Rb}-\mathrm{Sr}, \mathrm{Sm}-\mathrm{Nd}$, U-Pb, $\mathrm{Lu}-\mathrm{Hf}$ isotope data. Miner Petrol. doi:10.1007/s00710-012-0223-9

Pribavkin SV, Avdonina IS, Zamyatin DA (2012) Mineralogy, conditions of crystallization and melt generation of epidote-bearing porphyries from the Middle Urals, Russian federation. Miner Petrol. doi:10.1007/s00710-012-0226-6

Prochaska W, Krupenin M (2012) Formation of magnesite and siderite deposits in the Southern Urals - evidence of inclusion fluid chemistry. Miner Petrol. doi:10.1007/s00710-012-0251-5

Puchkov VN (2013) Structural stages and evolution of the Urals. Miner Petrol. doi:10.1007/s00710-012-0263-1 